\title{
UJI AKTIVITAS ANTIOKSIDAN Stylissa sp. DENGAN METODE DPPH (1,1-difenil-2-pikrilhidrazil)
}

\author{
Muhammad Setiawan Ikhrar'), Adithya Yudistira ${ }^{1)}$, Defny S. Wewengkang ${ }^{1)}$ \\ Program Studi Farmasi FMIPA UNSRAT Manado, 95115
}

\begin{abstract}
This study aims to analyze the antioxidant activity of Stylissa sp., sponge. The Stylissa sp., sponge sample was obtained from the Lembeh Strait, waters Bitung. This research is an experimental laboratory by testing the ethanol extracts of Stylissa sp., sponge using DPPH method (1,1-diphenil2-pikrihidrazil) to analyze antioxidant activity using a spectrophotometer. The results of this study show the antioxidant levels of the Stylissa sp., sponge in the Lembeh Strait waters have antioxidant activity and the higher the concentration the higher the antioxidant levels produced. The greatest antioxidant level is found in Stylissa sp., sponge with a concentration of 100 $m g / L$.
\end{abstract}

Keywords : Antioxidants, DPPH, Sponge Stylissa sp

\begin{abstract}
ABSTRAK
Penelitian ini bertujuan untuk menganalisis aktivitas antioksidan dari Stylissa sp. Sampel Spons Stylissa $s p$ di peroleh dari perairan Selat Lembeh, Bitung. Penelitian ini merupakan eksperimental laboratorium dengan pengujian terhadap ektrak etanol Spons Stylissa sp dengan metode DPPH (1,1diphenil-2-pikrihidrazil) untuk menganalisis aktivitas antioksidan dengan menggunakan sprektrofotometer. Hasil penelitian ini memperlihatkan kadar antioksidan dari Spons Stylissa sp di perairan Selat Lembeh mempunyai aktivitas antioksidan dan semakin tinggi konsenstrasi semakin tinggi pula kadar antioksidan yang dihasilkan. Kadar antioksidan yang paling besar terdapat pada Spons Stylissa sp dengan konsentrasi $100 \mathrm{mg} / \mathrm{L}$.
\end{abstract}

Kata kunci : Antioksidan, DPPH, Spons Stylissa sp 


\section{PENDAHULUAN}

Penelitian bahan bioaktif dari organisme laut beberapa tahun terakhir sangat banyak dilakukan, baik didalam maupun diluar negeri. Substansi bioaktif, terutama terdapat pada biota laut yang tidak bertulang belakang (avertebrata) seperti spons, koral dan tunikata. Biota tersebut mengandung senyawa aktif yang lebih banyak dibanding alga dan tumbuhan darat. Diantara biota laut tak bertulang belakang tersebut, spons menduduki tempat teratas sebagai sumber substansi aktif (Proksch, 1998).

Menurut Apri (2014), substansi kimia yang disekresikan karang lunak sebagai senyawa metabolit sekunder menarik untuk dikaji pemanfaatannya bagi sumber bahan obat-obatan alami. Oleh karena senyawa bioaktif yang terdapat pada spons sangat dipengaruhi oleh mikroba simbionnya, maka variasi dari senyawa bioaktif spons sangat tinggi.

Adanya radikal bebas didalam tubuh manusia berperan dalam patologi dari berbagai penyakit degeneratif yakni kanker, aterosklerosis, rematik, jantung koroner, katarak dan penyakit degenerasi saraf seperti parkinson (Silalahi, 2006).

Penggunaan senyawa antioksidan juga antiradikal saat ini semakin meluas seiring dengan semakin besarnya pemahaman masyarakat tentang peranannya dalam menghambat penyakit degeneratif seperti penyakit jantung, arteriosclerosis, kanker, serta gejala penuaan. Masalah-masalah ini berkaitan dengan kemampuan antioksidan untuk bekerja sebagai inhibitor (penghambat) reaksi oksidasi oleh radikal bebas reaktif yang menjadi salah satu pencetus penyakit-penyakit di atas (Tahir et al., 2003).

\section{METODOLOGI PENELITIAN}

\section{Waktu dan Tempat Penelitian}

Penelitian ini dilaksanakan pada bulan Oktober 2018 - Desember 2018 di Laboratorium Farmasi Lanjut Program Studi Farmasi, Fakultas Matematika dan Ilmu Pengetahuan Alam, Universitas Sam Ratulangi

\section{Bentuk Penelitian}

Bentuk dari penelitian ini adalah eksperimental laboratorium yang akan menguji aktivitas antioksidan dengan menggunakan metode DPPH (1,1-difenil2-pikrilhidrazil) dari ekstrak etanol spons Stylissa sp. dari perairan Selat Lembeh.

\begin{abstract}
Alat
Alat-alat yang digunakan dalam penelitian ini ialah Scuba diving dan juga alat-alat gelas seperti gelas $500 \mathrm{~mL}$ (pyrex), labu ukur $10 \mathrm{~mL}$ (pyrex), gelas ukur $1000 \mathrm{~mL}$ (pyrex), Erlenmeyer 500 $\mathrm{mL}$, cawan petri, cawan porselin, wadah botol, timbangan digital (AE ADAM), spektrofotometer UV-Vis , aluminium foil, rotary evaporator, pipet tetes, corong, mikro pipet, pipet volume.
\end{abstract}

\section{Bahan}

Bahan yang digunakan dalam penelitian ini yaitu kertas saring, etanol 96\%, etanol, DPPH (1,1-difenil-2pikrilhidrazil), ekstrak etanol dari spons Stylissa sp. dan serbuk vitamin C p.a sebagai kontrol positif. 


\section{Pengambilan Sampel}

Sampel ini diambil di perairan selat lembeh menggunakan alat bantu (scuba diving). Sebelum diambil sampel di foto menggunakan kamera bawah laut setelah diambil di masukan dalam kantong plastik jepit yang sudah di siapkan dan di simpan dalam kotak pendingin lalu di bawah ke Laboratorium Farmasi Lanjut Program Studi Farmasi Universitas Sam Ratulangi.

\section{Preparasi Sampel}

Spons Stylissa sp. yang di sudah di ambil di cuci kembali dan di potong-potong kecil lalu di masukan kedalam wadah botol, sampel yang di dalam botol di isi dengan etanol 96\% sebanyak $200 \mathrm{~mL}$.

\section{Ekstraksi Sampel}

Sampel spons Stylissa sp. sebanyak 140 g di maserasi dengan pelarut etanol 96\% sebanyak 200mL dengan 3 kali pengulangan selama 24 jam dengan sesekali di kocok. Hasil dari maserasi kemudian di saring untuk mendapatkan hasil filtrat, kemudian hasil filtrat yang di dapatkan dari 3 kali pengulangan di uapkan menggunakan rotary evaporator sehingga menghasilkan ekstrak kental dari sampel, lalu di taruh di cawan petri dan di masukan kedalam oven pemanas untuk mendapatkan ekstrak kasar dari sampel spons Stylissa sp.

\section{Pembuatan Larutan Stok}

Sebanyak $100 \mathrm{mg}$ ekstrak spons Stylissa sp. dilarutkan dalam $100 \mathrm{~mL}$ etanol 96\%. Dengan masing-masing konsentrasi 100, 75, 50 dan $25 \mathrm{mg} / \mathrm{L}$, dihitung dengan menggunakan rumus pengenceran, yaitu :

$$
\mathbf{V}_{1} \cdot \mathbf{M}_{1}=\mathbf{V}_{\mathbf{2}} \cdot \mathbf{M}_{\mathbf{2}}
$$

Dari masing-masing hasil yang didapatkan dari hasil $\mathrm{V}_{1}$ dipipet dan ditambahkan etanol 96\% hingga mencapai tanda batas (10 mL), kemudian dipindahkan ke dalam tabung reaksi dan ditutup dengan menggunakan aluminium foil untuk digunakan pada perlakuan selanjutnya.

\section{Pembuatan Larutan DPPH}

Sebanyak $4 \mathrm{mg}$ DPPH ditimbang dan dilarutkan dalam etanol $96 \%$ sebanyak $100 \mathrm{~mL}$, dan buat larutan stok DPPH sesuai konsentrasi yang sama dengan konsentrasi pada larutan stok sebelumnya yaitu 100, 75, 50 dan 25 . Pada masingmasing konsentrasi, ditambahkan etanol sampai tanda batas (10 mL). Selanjutnya larutan yang di buat untuk uji aktivitas antioksidan yaitu ekstrak etanol spons Stylissa sp. di pipet sebanyak 0,5 mL dimasukan kedalam tabung reaksi dengan masing-masing konsentrasi 100, 75, 50 dan $25 \mathrm{mg} / \mathrm{L}$ dan di tambahkan $1,5 \mathrm{~mL}$ larutan DPPH kedalam masing-masing kosentrasi dan divortex selama 2 detik. Sampel dibuat sebanyak 3 kali pengulangan.

\section{Pembuatan Larutan Vitamin C (p.a)}

Vitamin C p.a ditimbang sebanyak 10 mg. Kemudian, vitamin $\mathrm{C}$ p.a dilarutkan dalam etanol p.a sebanyak $10 \mathrm{~mL}$, buat larutan stok dengan konsentrasi yang sama, yaitu konsentrasi 100, 75, 50 dan $25 \mathrm{~mL}$ dengan ditambahkan masingmasing larutan dengan etanol p.a mencapai tanda batas $(10 \mathrm{~mL})$, dengan 
pengulangan sebanyak 3 kali pada masing-masing konsentrasi. Sampel vitamin C p.a diuji pada spektrofotometer UV-Vis dengan panjang gelombang 517 $\mathrm{nm}$.

\section{Pengujian Larutan Kontrol DPPH dan Aktivitas Atioksidan dengan Metode DPPH}

Larutan kontrol DPPH diuji pada spektrofotometer UV-Vis dengan panjang gelombang $517 \mathrm{~nm}$ sebagai absorbansi kontrol dalam pengujian ini. Sampel diinkubasi selama 30 menit pada suhu $37^{\circ} \mathrm{C}$. Untuk mengetahui aktivitas dari penangkal radikal bebas tersebut, di uji pada spektrofotometer. Berubahnya warna ungu menjadi warna kuning menunjukkan efisiensi penangkal radikal bebas. Diukur absorbansi pada spektrofotometer UV-Vis dengan panjang gelombang $517 \mathrm{~nm}$ setelah diinkubasi selama 30 menit berubahnya warna menjadi kuning menunjukkan bahwa, masing-masing konsentrasi menunjukkan efisiensi penangkal radikal bebas di uji dengan spektrofotometer UV-Vis dengan panjang gelombang $517 \mathrm{~nm}$.

Kemudian diamati perbandingannya dengan vitamin C p.a sebagai standar. Aktivitas penangkapan radikal bebas (persen inhibisi) dihitung sebagai persentase berkurangnya warna DPPH dengan menggunakan rumus :

$$
\begin{aligned}
& \% \text { inhibisi } \\
& =1 \\
& -\frac{\text { absorbansi sampel }}{\text { absorbansi kontrol }} \times 100 \%
\end{aligned}
$$

\section{HASIL DAN PEMBAHASAN}

Pengujian ini dilakukan untuk mengetahui aktivitas dari penangkal radikal bebas, di uji pada spektrofotometer. Hasil pengujian

\begin{tabular}{|c|c|c|c|c|c|}
\hline \multicolumn{2}{|c|}{ Konsentrasi } & $\begin{array}{c}\text { Pengulangan } \\
\text { I }\end{array}$ & $\begin{array}{l}\text { Pengulangan } \\
\text { sp. II }\end{array}$ & $\begin{array}{c}\text { Pengulangan } \\
\text { III }\end{array}$ & $\begin{array}{l}\text { Rata- } \\
\text { rata }\end{array}$ \\
\hline \multirow{2}{*}{$\begin{array}{c}25 \\
\mathrm{mg} / \mathrm{L}\end{array}$} & Ekstrak & $66,60 \%$ & $65,50 \%$ & $65,70 \%$ & $65,90 \%$ \\
\hline & Vit C & $93,90 \%$ & $94 \%$ & $93,90 \%$ & $93,90 \%$ \\
\hline \multirow{2}{*}{$\begin{array}{c}50 \\
\mathrm{mg} / \mathrm{L}\end{array}$} & Ekstrak & $67,10 \%$ & $66,30 \%$ & $65,60 \%$ & $66,30 \%$ \\
\hline & Vit C & $92,90 \%$ & $93,60 \%$ & $93,60 \%$ & $93,30 \%$ \\
\hline \multirow{2}{*}{$\begin{array}{c}75 \\
\mathrm{mg} / \mathrm{L}\end{array}$} & Ekstrak & $69,60 \%$ & $68,60 \%$ & $69,70 \%$ & $69,30 \%$ \\
\hline & Vit C & $93,80 \%$ & $93,30 \%$ & $93,80 \%$ & $93,60 \%$ \\
\hline \multirow{2}{*}{$\begin{array}{c}100 \\
\mathrm{mg} / \mathrm{L}\end{array}$} & Ekstrak & $69,70 \%$ & $71,20 \%$ & $69,90 \%$ & $70,26 \%$ \\
\hline & Vit C & $93,90 \%$ & $93,90 \%$ & $93,60 \%$ & $93,80 \%$ \\
\hline
\end{tabular}
disajikan pada tabel dibawah ini :

Tabel 1. Hasil perbandingan pengujian Aktivitas Antioksidan Ekstrak Etanol Stylissa 
Spons merupakan biota laut yang hidup menetap di dasar perairan, yang memiliki peran yang cukup penting di dalam ekosistem terumbu karang. Selain itu spons merupakan salah satu komponen biota penyusun terumbu karang yang mempunyai potensi bioaktif yang belum banyak dimanfaatkan. Hewan laut ini mengandung senyawa aktif yang persentase keaktifannya lebih besar dibandingkan dengan senyawasenyawa yang dihasilkan oleh tumbuhan darat contohnya pada biota laut spons Stylissa sp. (Rachmaniar, 1998).

Ekstraksi pada spons Stylissa sp. menggunakan proses maserasi, dimana sediaan cair yang dibuat dengan cara mengekstraksi bahan nabati yaitu direndam menggunakan pelarut bukan air (pelarut nonpolar) atau setengah air, misalnya etanol encer, selama periode

waktu tertentu, waktu yang digunakan untuk perlakuan ini selama 24 jam untuk $3 x$ pengulangan dengan sampel sebanyak 180 g. Kelebihan dari ekstraksi dengan metode maserasi adalah Unit alat yang dipakai sederhana, hanya dibutuhkan bejana perendam Biaya operasionalnya relatif rendah Prosesnya relatif hemat penyari dan tanpa pemanasan.

Pembuatan larutan stok dimana pada umumnya dinyatakan dalam kelipatan konsentrasi media yaitu 10x, 20x, 100x, bahkan 1000x konsentrasi media. Pada penelitian ini dilakukan pengujian dengan pengulangan konsentrasi 25, 50, 75, dan $100 \mathrm{mg} / \mathrm{L}$. Pada pembuatan larutan stok harus memperhatikan daya simpan larutan karena larutan yang apabila sudah mengalami pengendapan tidak dapat digunakan lagi. Pengendapan larutan stok umumnya terjadi bila kepekatan larutan terlalu tinggi.

Tujuan dari pembuatan larutan stok sendiri ialah untuk menghindari penimbangan yang berulang-ulang setiap kali membuat media dimana penimbangan berulang-ulang ini lebih membutuhkan banyak waktu. Dengan adanya larutan stok lebih memudahkan karena pembuatan media selanjutnya tinggal mengencerkan larutan stok saja larutan stok dibuat hanya untuk satu jenis bahan. Langkah ini bertujuan untuk menghindari pengendapan larutan.

Metode yang digunakan pada penelitian ini adalah DPPH (1,1-difenil-2pikrilhidrazil). karena merupakan metode yang paling sering digunakan untuk menguji aktivitas antioksidan tanaman obat adalah metode uji dengan menggunakan radikal bebas DPPH. Tujuan metode ini adalah mengetahui parameter konsentrasi yang ekuivalen memberikan $50 \%$ efek aktivitas antioksidan (IC50). Hal ini dapat dicapai dengan cara menginterpretasikan data eksperimental dari metode tersebut. DPPH merupakan radikal bebas yang dapat bereaksi dengan senyawa yang dapat mendonorkan atom hidrogen, dapat berguna untuk pengujian aktivitas antioksidan komponen tertentu dalam suatu ekstrak.

Sebanyak $4 \mathrm{mg}$ DPPH ditimbang dan dilarutkan dalam etanol $96 \%$ sebanyak $100 \mathrm{~mL}$, dan buat larutan stok DPPH sesuai konsentrasi yang sama dengan konsentrasi pada larutan stok sebelumnya yaitu 100, 75, 50 dan 25 . Pada masing-masing konsentrasi, ditambahkan etanol sampai tanda batas 
(10 mL). Selanjutnya larutan yang di buat untuk uji aktivitas antioksidan yaitu ekstrak etanol spons Stylissa sp. di pipet sebanyak $0,5 \mathrm{~mL}$ dimasukan kedalam tabung reaksi dengan masing-masing konsentrasi 100, 75, 50 dan $25 \mathrm{mg} / \mathrm{L}$ dan di tambahkan 1,5 mL larutan DPPH kedalam masing-masing kosentrasi dan divortex selama 2 detik. Sampel dibuat sebanyak 3 kali pengulangan.

Pada penelitian ini menggunakan vitamin C p.a sebagai Pembanding untuk kontrol positif sampel spons Stylissa sp. karena berfungsi sebagai antioksidan sekunder yaitu menangkap radikal bebas, mencegah terjadinya reaksi berantai, aktivitas antioksidannya sangat tinggi, mudah diperoleh dan vitamin $\mathrm{C}$ lebih polar dari vitamin yang lain. Vitamin $\mathrm{C}$ mempunyai gugus hidroksi bebas yang bertindak sebagai penangkap radikal bebas.

Sebelum memasuki pengujian dengan alat spektrofotometer UV-Vis, sampel spons Stylissa sp. dan larutan sampel vitamin C p.a diinkubasi terlebih dahulu dengan cara menutup sampel dengan aluminium foil selama 30 menit. Spektrofotometer umum digunakan karena kemampuannya dalam menganalisa begitu banyak senyawa kimia serta kepraktisannya dalam hal preparasi sampel apabila dibandingkan dengan beberapa metode analisa. Spektrofotometri UV/Vis melibatkan energi elektronik yang cukup besar saat analisis, sehingga spektrofotometer UV/Vis lebih banyak dipakai untuk analisis kuantitatif dibanding kualitatif. Spektrofotometri UV-vis adalah pengukuran serapan cahaya di daerah ultraviolet $(200-350 \mathrm{~nm})$ dan sinar tampak $(350-800 \mathrm{~nm})$ oleh suatu senyawa.

Pada konsentrasi 25, 50, 75 dan 100 $\mathrm{mg} / \mathrm{L}$ Hasil pengukuran aktivitas antioksidan pada larutan sampel spons Stylissa sp. menunjukkan bahwa spons Stylissa sp. memiliki aktivitas antioksidan yang cukup tinggi hal ini dapat dilihat pada (Tabel 1) dengan ratarata $65,90 \%$ di konsentrasi $25 \mathrm{mg} / \mathrm{L}$, 66,30\% di konsentrasi $50 \mathrm{mg} / \mathrm{L}, 69,30 \%$ di konsentrasi $75 \mathrm{mg} / \mathrm{L}$ dan yang paling besar di konsentrasi $100 \mathrm{mg} / \mathrm{L}$ yaitu sebesar $70,26 \%$ berbanding dengan aktivitas pada konsentrasi sampel spons Stylissa sp. dengan kontrol positif dari sampel vitamin $\mathrm{C}$ yang tinggi hal ini dapat dilihat pada (tabel 1) dengan ratarata 93,90\% di konsentrasi $25 \mathrm{mg} / \mathrm{L}$, 93,30 \% di konsentrasi 50 mg/L, 69,30\% di konsentrasi.

$75 \mathrm{mg} / \mathrm{L}$ dan yang paling besar di konsentrasi $100 \mathrm{mg} / \mathrm{L}$ yaitu sebesar 93,80\%. Berdasarkan hasil yang diperoleh pada (Tabel 1) menunjukkan bahwa pengukuran persen inhibisi pada ekstrak etanol spons Stylissa sp. memiliki aktivitas antioksidan dan mengalami peningkatan dari konsentrasi $25 \mathrm{mg} / \mathrm{L}$ sampai dengan $100 \mathrm{mg} / \mathrm{L}$. Pada ekstrak etanol spons Stylissa sp. dengan konsentrasi $100 \mathrm{mg} / \mathrm{L}$ memiliki persen inhibisi rata-rata paling tinggi yaitu sebesar 70,26\% Penigkatan persen inhibisi pada ekstrak etanol spons Stylissa sp. menandakan bahwa konsentrasi ekstrak yang ditambahkan mempengaruhi kemampuan ekstrak dalam merendam radikal bebas.Hal ini didukung oleh penelitian yang dilakukan oleh Hanani et al., (2005) sebagai jurnal pembanding yang menyatakan bahwa presentasi 
penghambat atau persen inhibisi terhadap aktivitas radikal bebas akan ikut meningkat seiring dengan meningkatnya konsentrasi. Hasil pengujian perbandingan aktivitas antioksidan ekstrak spons Stylissa sp. dan vitamin C (Tabel 1) juga menukjukkan bahwa aktivitas antioksidan ekstrak etanol spons Stylissa sp. lebih rendah dibandingkan dengan vitamin $\mathrm{C}$.

\section{KESIMPULAN}

Berdasarkan dari hasil penelitian yang telah dilakukan dapat disimpulkan bahwa ekstrak etanol spons Stylissa sp. dari Perairan Selat Lembeh, Kota Bitung memiliki aktivitas antioksidan.

\section{SARAN}

Perlu dilakukan penelitian lebih lanjut untuk mengetahui senyawa aktif yang terkandung dalam spons Stylissa sp. dan pengujian aktivitas antioksidan dengan metode lain dan sebaiknya membandingkan hasilnya dengan penelitian ini.

\section{DAFTAR PUSTAKA}

Apri, R. 2014. Kandungan Senyawa Bioaktif Dan Uji Fitokimia Sinularia sp dan Lobophytum sp Dari Perairan Pulau Pongkok Bangka Selatan. Thesis. Sekolah Pascasarjana Institut Pertanian Bogor, Bogor. 50 hal.

Hanani E, Mun'im B, Sekarini R. 2005. Identifikasi senyawa antioksidan dalam spons Callispongia sp. dari Kepulauan Seribu.Jurnal Ilmu Kefarmasian2 (3) : 127-133. Jurnal (Endang Hanani).
Proksch, P. 1998. Pharmacologically Active Natural Product from Marine Invertebrates and Associated Microorganisms. Prosiding Seminar Bioteknologi I, Ed. Rachmaniar et al., Puslit Oseanologi LIPI, Jakarta.

Rachmaniar. 2003. Produk Alam Laut Sebagai Lead Compound Untuk Farmasi Dan Pertanian, Dibawakan Pada Seminar Sehari Perfektif Baru Dalam Drug, Discovery, Makassar, 26 Oktober 2003.

Silalahi, J. 2006. Makanan Fungsional. Kanisius. Jogjakarta.

Tahir, I., Wijaya, K., dan Widianingsih, D. 2003. Terapan Analisis Hansch Untuk Aktivitas Antioksidan Senyawa Turunan Flavon/Flavonol. Artikel Seminar Chemometrics- Chemistry. Dept Gadjah Mada University, Yogyakarta. 